\title{
Perswazyjność przekazu a problem legitymizacji władzy
}

\section{Wstęp}

Celem artykułu jest odpowiedź na pytanie, czy zastosowane językowe środki perswazji w komunikowaniu politycznym stanowią racjonalną podstawę legitymizacji demokratycznego systemu politycznego. W odpowiedzi na to pytanie posłużę się koncepcją „idealnej sytuacji komunikacyjnej” autorstwa Jürgena Habermasa $^{1}$. Intuicyjnie, wręcz a priori, autor tekstu zakłada, że komunikowanie polityczne, ze swej natury, zawiera elementy perswazyjne. Celem badań nie jest zatem stwierdzenie, że w komunikowaniu polityków zawarte są elementy perswazyjne. To uznać należy za oczywiste, podobnie jak pytanie retoryczne, które nie domaga się odpowiedzi.

Do analizy wybrałem przemówienia włoskich polityków: premiera Matteo Renzi oraz lidera partii Ruch Pięciu Gwiazd (MoVimento 5 Stelle) Beppe Grillo w Parlamencie Europejskim w Strasburgu z 2 lipca 2014 roku, a także wystąpienie Grillo podsumowujące rok 2014 (z 31 grudnia 2014 roku) oraz przemówienie Silvio Berlusconiego z 28 listopada 2013 roku, będące jego ostatnim przemówieniem jako senatora² ${ }^{2}$ Okoliczności wystąpień są zatem znaczące i związane z czasem,

*Dr, e-mail: rafalles@vp.pl; Uniwersytet Kardynała Stefana Wyszyńskiego w Warszawie, Instytut Edukacji Medialnej i Dziennikarstwa; 01-815 Warszawa, ul. Dewajtis 5.

${ }^{1}$ Por. J. Habermas, Vorstudien und Ergänzungen zur Theorie des kommunikativen Handelns, Frankfurt am Main 1984, S. 177-178.

${ }^{2}$ Analizowane przemówienia dostępne są w internecie:

- przemówienie premiera M. Renzi w Parlamencie Europejskim w Strasburgu, 2.07.2014, http:// archivio.internazionale.it/news/unione-europea/2014/07/02/il-discorso-integrale-di-matteorenzi-al-parlamento-europeo [dostęp: 4.11.2015];

- przemówienie B. Grillo w Parlamencie Europejskim w Strasburgu, 2.07.2014, https://www. youtube.com/watch? $\mathrm{v}=\mathrm{cbkaEeG721Y}$ [dostęp: 4.11.2015];

- przemówienie B. Grillo podsumowujące rok 2014, 31.12.2014, http://www.beppegrillo.it/videos/0_s49orvgm.php [dostęp: 4.11.2015], http://www.repubblica.it/2004/a/sezioni/politica/festaforza/discesa/discesa.html [dostęp: 4.11.2015];

- przemówienie S. Berlusconiego jako senatora, 28.11.2013, https://www.youtube.com/watch?v=go4FPwf0aVI [dostęp: 4.11.2015]. 
w którym zainteresowanie włoskiej opinii publicznej koncentruje się wokół kwestii kryzysu gospodarczego, narastającego zadłużenia państw, wzrastającego bezrobocia, zwłaszcza wśród ludzi młodych. Przemówienia premiera Włoch Renzi i lidera Ruchu Pięciu Gwiazd w Strasburgu mają miejsce na samym początku półrocznej prezydencji Włoch w Radzie Unii Europejskiej i wpisują się w przestrzeń trapiących Europę problemów3. Podobnie w ten kontekst sytuacyjny wpisuje się Grillo ze swoim przemówieniem kończącym rok 2014. Przemówienie Berlusconiego z roku 2013 domyka ważny etap jego kariery politycznej jako senatora.

Dlaczego autor wybrał do analizy właśnie reprezentantów świata włoskiej polityki? Autora od wielu lat interesują zagadnienia związane z komunikowaniem politycznym Włoch, kraju o długiej historii demokracji, będącego spadkobiercą starożytnych retorów Imperium Rzymskiego. Kilkuletni pobyt w Italii pozwolił mu „bardziej z bliska” przyjrzeć się sposobom komunikacji włoskiej sceny polityki. Oczywiście, by znaleźć poprawną odpowiedź na pytanie badawcze, postawione na początku tekstu, można byłoby do analizy wybrać inny kraj, innych mówców, inne okoliczności dyskursu.

Politycy, których przemówienia stały się przedmiotem analizy językowej w niniejszym artykule, należą do najważniejszych osobistości włoskiej polityki. Kryterium ważności stanowi ranking z 2014 roku opublikowany w wersji internetowej tygodnika „Panorama”, w którym Renzi, Berlusconi i Grillo zajmują najwyższe miejsca w kategorii „10 najważniejszych polityków włoskich 2014 roku”4.

Matteo Renzi od 22 lutego 2014 roku sprawuje urząd premiera Włoch. Początek jego działalności politycznej miał miejsce w latach 90. XX wieku. Związany jest z Włoską Partią Ludową, ugrupowaniem Margherita oraz współtworzy Partię Demokratyczną. W latach 2004-2009 piastował urząd prefekta prowincji Florencja, zaś od 2009 do 2014 roku był burmistrzem Florencji ${ }^{5}$.

Beppe Grillo ma 67 lat, jest włoskim komikiem, aktorem, założycielem i liderem eurosceptycznej partii politycznej Ruch Pięciu Gwiazd, głoszącej hasła populistyczne, ekologiczne, antykorupcyjne ${ }^{6}$. Prowadzi blog beppegrillo.it, który

W podjętej analizie przemówienie Renzi w Parlamencie Europejskim w Strasburgu oznaczę jako Renzi_1, wystąpienie Grillo w tymże parlamencie jako Grillo_1, przemówienie podsumowujące r. 2014 jako Grillo_2, przemówienie S. Berlusconiego jako Berlusconi_1.

${ }^{3}$ Por. I. Dziurlikowska, Włoska prezydencja pod znakiem rozwoju, http://www.uniaeuropejska.org/wloska-prezydencja-pod-znakiem-rozwoju [dostęp: 4.11.2015].

${ }^{4}$ Por. C. Daconto, I 10 politici più importanti del 2014, http://www.panorama.it/news/politica/i10-politici-piu-importanti-2014/ [dostęp: 4.11.2015].

${ }^{5}$ Por. Matteo Renzi, la mia storia. Chi sono, http://www.matteorenzi.it/chi-sono/ [dostęp: 4.11.2015].

${ }^{6}$ Por. Chi c'è dietro Beppe Grillo? Ritratto di Casaleggio, lo stratega 5Stelle, http://www. iltempo.it/politica/2012/10/01/chi-c-e-dietro-beppe-grillo-ritratto-di-casaleggio-lo-stratega5stelle-1.3130 [dostęp: 11.02.2015]; Beppe Grillo: humorysta, bloger, polityk, http://pl.euronews. com/2012/05/22/beppe-grillo-humorysta-bloger-polityk/ [dostęp: 4.11.2015]. 
w opinii brytyjskiego dziennika „The Guardian” należy do najbardziej wpływowych na świecie?.

Silvio Berlusconi to 79-letni polityk włoski, lider partii Forza Italia, który trzykrotnie sprawował urząd premiera Włoch (1994-1995, 2001-2006, 2008-2011). Zaliczany jest do najbogatszych obywateli Włoch, jest właścicielem m.in. grupy bankowej Banca Mediolanum, krajowej sieci księgarni Mondadori, a także klubu piłkarskiego AC Milan ${ }^{8}$.

\section{„Idealna sytuacja komunikacyjna” według koncepcji Habermasa}

Niemiecki socjolog i filozof Jürgen Habermas zauważa, że działania z zakresu komunikacji politycznej umożliwiają w państwie demokratycznym dochodzenie do konsensusu, do wypracowania wspólnych definicji. Jego zdaniem w systemach demokratycznych publiczny dyskurs polityczny powinien dążyć do współdziałania uczestników debaty, harmonijnej współpracy w realizacji istotnych społecznych celów, choć jednocześnie bardzo ważna jest powszechność uczestnictwa w komunikacji politycznej ${ }^{9}$. Należy w tym miejscu podkreślić, że w dużej mierze to mass media decydują o tym, że uczestnikami publicznych wystąpień polityków mogą być obywatele państw różnych szerokości i długości geograficznych. Habermas proponuje państwom demokratycznym $\mathrm{w}$ ich myśleniu politycznym pewien passus od racjonalności technicznej do racjonalności komunikacyjnej. Z kolei owocem racjonalności komunikacyjnej jest zdefiniowanie prawdziwych wartości i celów danej społeczności ${ }^{10}$. Różnorodność opinii politycznych, dzięki dyskusji politycznej, powinna przyczynić się do odnalezienia właściwego konsensusu. Obywatelska refleksja nad sprawami państwa jest współczesnym areopagiem działań komunikacyjnych. Oczywiście pozostaje otwarte pytanie dotyczące tego, czy współcześni politycy w swoich publicznych wystąpieniach troszczą się o to, by koncepcja Habermasa znalazła swoje odniesienie w aktach komunikacyjnych przez nich tworzonych. „Idealna sytuacja komunikacyjna” według niemieckiego socjologa to taka, która spełnia kilka warunków, w jakich powinien być prowadzony

\footnotetext{
${ }^{7}$ The world's 50 most powerful blogs, http://www.theguardian.com/technology/2008/mar/09/ blogs [dostęp: 4.11.2015].

${ }^{8}$ Por. R. Capek-Habekovič, S. Palaich, Parola a te!, Heinle Cengage Learning, Boston 2009, p. 47; Silvio Berlusconi, http://ludzie.wprost.pl/sylwetka/Silvio-Berlusconi/ [dostęp: 4.11.2015].

${ }^{9}$ Por. J. Fras, Komunikacja polityczna. Wybrane zagadnienia gatunków i języka wypowiedzi, Wydawnictwo UWr, Wrocław 2005, s. 242-244.

${ }^{10}$ Por. P. Baciak, Internet - Agora XXI wieku? Rozważanie w świetle teorii demokracji deliberatywnej autorstwa Jürgena Habermasa, „Global Media Journal - Polish Edition” 2006, nr 2 (2), s. 136-139, http://globalmediajournal.collegium.edu.pl/artykuly/jesien\%202006/Baciak-Internet\%20-\%20Agora\%20XXI\%20wieku.pdf [dostęp: 4.11.2015].
} 
dyskurs, aby mógł zostać uznany za racjonalną podstawę legitymizacji demokratycznego systemu politycznego. Do tych warunków należą: równość między partnerami dyskursu, kompletne ujawnienie procesów deliberacji, czasowe wstrzymanie stosunków władzy i dominacji, wolność wyboru tematu dyskusji1".

W tekście autor dokonuje oceny, czy warunki te zostały spełnione w publicznych dyskursach polityków, czy też nie. Ocenia on również wpływ użytych środków perswazji na spełnienie wymienionych wyżej kryteriów decydujących o uznaniu bądź nieuznaniu przemówienia polityka za racjonalny fundament legitymizacji demokratycznego systemu politycznego. Teoria Habermasa, która jest koncepcją tylko teoretyczną, wskazuje na istniejące odniesienia pomiędzy aktami komunikacyjnymi a polityką.

Indywidualne predyspozycje intelektualne i moralne wygłaszającego dyskurs należy także wziąć pod uwagę w obiektywnej ocenie spełnienia warunków, o których wspomina Habermas. Starożytni mistrzowie słowa, do których można zaliczyć Arystotelesa, Cycerona czy Kwintyliana, podkreślali w swoich dziełach doniosłość etosu mówcy. W Etyce nikomachejskiej Stagiryta odnotowuje, że cnota jest „trwałą dyspozycją, dzięki której człowiek staje się dobry i dzięki której spełniać będzie należycie właściwe sobie funkcje"12. Do ważnych przymiotów wygłaszającego dyskurs filozof zalicza umiarkowanie, roztropność, męstwo $^{13}$. Gdyby, w myśl Stagiryty, mówca chciał sprzeniewierzyć się prawdzie, znieważyłby zarówno swego słuchacza, jak i zaprzeczył swojej racjonalności. Cyceron zauważa, że dobry mówca to ten, który jest osobą kompetentną, zabiera głos w sprawach, na których się zna i odnośnie do których nabył stosowne wykształcenie. Poza tym, zdaniem tego rzymskiego pisarza i retora, istotne jest, aby mówca był mędrcem i posiadał stosowne cnoty ${ }^{14}$. Kwintylian w dziele Ksztatcenie mówcy (Institutionis oratoriae), podkreśla, że ,prawdziwym obywatelem powołanym do kierowania sprawami publicznymi i prywatnymi, który mógłby rozważnie rządzić państwami, zasadzać je na prawach, wyzwalać z błędów wyrokiem sądowym, jest naprawdę nie kto inny, jak tylko mówca"15.

\footnotetext{
${ }^{11}$ Por. J. Habermas, dz. cyt.; P. Baciak, dz. cyt.; A. Gimmler, Deliberative Democracy, the Public Sphere and the Internet, „Philosophy \& Social Criticism” 2001, Vol. 27, pp. 21-39; M. Żardecka-Nowak, Demokracja deliberatywna jako remedium na ponowoczesny kryzys legitymizacji władzy, „Teka Komisji Politologii i Stosunków Międzynarodowych. Polska Akademia Nauk Oddział w Lublinie" 2008, III, s. 29-40, http://www.pan-ol.lublin.pl/wydawnictwa/TPol3/Zardecka. pdf [dostęp: 4.11.2015].

${ }^{12}$ Arystoteles, Etyka nikomachejska, za: Aristotelis, Ethica Nicomachea, recognovit F. Susemihl, Teubner, Lipsiae 1880, H1106a 20-23.

${ }^{13}$ Arystoteles, Etyka wielka, [w:] tenże, Dzieła wszystkie, t. 5, przeł. D. Gromska, Wydawnictwo Naukowe PWN, Warszawa 1996, s. 338-344.

${ }^{14}$ Por. M.T. Cyceron, O mówcy, przeł. B. Awianowicz, Wydawnictwo Antyk, Warszawa 2011, s. 97.

${ }^{15}$ Kwintylian, Kształcenie mówcy. Księgi I, II i X, przeł. i oprac. M. Brożek, Ossolineum, Wrocław 1951, s. 10.
} 
Wzmianka o starożytnych wzorcach dobrych mówców dowodzi, że w ocenie relacji pomiędzy perswazyjnością przekazu a problemem legitymizacji władzy ważne jest nie tylko stosowne użycie środków językowej perswazji, ale także i etos mówcy. Istotną kwestią jest zatem wiedzieć nie tylko, co i w jaki sposób polityk powiedział, ale także należy wiedzieć, kim jest nadawca komunikatu. Będzie to pomocne w poddanych analizie przemówieniach.

\section{Analiza wybranych przemówień}

Językowe środki perswazji - figury retoryczne

Na początku doprecyzuję, co rozumiem przez termin ,perswazja”. Posłużę się definicją wybitnego polskiego językoznawcy i prasoznawcy Walerego Pisarka. Stwierdza on, że perswazja to

starania o wywarcie bez przymusu za pomocą przekazów (słownych i pozasłownych) i zawartej w nich argumentacji (racjonalnej i emocjonalnej), stanowiącej wynik selekcji treści i form, wpływu na przekonania, opinie, postawy, nastroje, a co za tym idzie i na zachowania adresata/adresatów tych przekazów ${ }^{16}$.

Perswazja w odróżnieniu od manipulacji ma miejsce wtedy, gdy następuje przekazywanie racjonalnych i prawdziwych informacji, tymczasem manipulacja w sposób świadomy i celowy zniekształca lub fałszuje informacje. Zdaniem amerykańskiego socjologa i politologa Roberta Dahla, perswazja stanowi dialektykę współczesnej rzeczywistości, zaś manipulacja jest pozorem lub kłamstwem ${ }^{17}$.

Perswazyjność przekazu jest zatem zabiegiem mówcy, który próbuje wpłynąć na działania słuchacza. Istnieją różnorodne techniki perswazyjności przekazu. W tym miejscu wymienię te techniki, których obecność dostrzegłem w podjętej analizie, a mianowicie: stosowanie formuł impresywnych i wyrażeń o charakterze powinnościowym; wolitywny charakter wypowiedzi; figury retoryczne (np. emfaza, enumeracja, porównanie, powtórzenie, wyznanie, pytanie retoryczne).

Formuły impresywne, np. trzeba, musieć, do nas należy, wskazują na powinność wykonania jakiejś czynności, w której zostaje zaangażowany słuchacz. Poniżej przywołuję kilka przykładów tychże form, które można odnaleźć w tekście badanych przemówień polityków:

${ }^{16}$ W. Pisarek, Perswazja - jak ja widza, jak ja pisza, [w:] Język perswazji publicznej, red. K. Mosiołek-Kłosińska, T. Zgółka, Wydawnictwo Poznańskie, Poznań 2003, s. 15.

${ }^{17}$ Por. M. Nieć, Komunikowanie społeczne i media. Perspektywa politologiczna, LEX Grupa Wolters Kluwer, Warszawa 2010, s. 229. 
Renzi_1 (10:22) "To musi być pozytywny fakt”. (Questo deve essere un fatto positivo.) Renzi_1 (18:45) „To musimy uczynić ze względu na nasze dzieci”. (Lo dobbiamo ai nostri figli.)

Berlusconi_1 (0:22) „Musimy pozostać w grze. Nie załamujmy się, nawet jeśli lider centroprawicy nie jest już senatorem". (Dobbiamo restare in campo. Non disperiamoci se il leader centrodestra non è più senatore.)

Grillo_1 (09:18) „Należy uczynić przeskok w myśleniu”. (Bisogna fare un salto di immaginazione.)

Grillo_1 (11:38) „Należy usiąść i rozpocząć myślenie”. (Qui bisogna sedersi ed incominciare a ragionare.)

Grillo_1 (14:31) „Tu potrzebny jest psychiatra, by to zrozumieć”. (Ci vuole un psichiatra per capire.)

Grillo_1 (17:03) „Należy usiąść i zastanowić się, w jakim świecie chcemy żyć”. (Qui bisogna sederci e ripensare in che mondo vogliamo vivere.)

Grillo_1 (20:08) „Musimy to wyciągnąc na zewnątrz”. (Dobbiamo tirare fuori.)

Grillo_2 (02:39) „Oto dlaczego należy mówić szeptem”. (Ecco, perché bisogna parlare sottovoce.)

Formy 1. osoby liczby mnogiej czasownika oraz zaimek osobowy my i dzierżawczy nasz w języku polityków mają za zadanie utożsamić słuchaczy z mówcą w kwestii jego przekonań i poglądów. Tę technikę perswazyjności przekazu wyrażają następujące przykłady:

Renzi_1 (02:05): „Czym jest dziś debata nad polityką europejską po kryzysie, który my wszyscy przeżyliśmy i który [to] kryzys przeżywamy?" (Che cos'è oggi il dibatto sulla politica europea dopo la crisi che tutti abbiamo vissuto e che la crisi che stiamo vivendo?)

Renzi_1 (03:11) „Jeżeli zatrzymamy się na moment, by rozważyć, pomyślmy...”. (Se ci fermiamo un secondo a riflettere e immaginiamo...)

Renzi_1 (04:27) „Nie wierzę, że możemy umniejszyć kwestie finansowe”. (Non credo che possiamo sottovalutare la questione finanziaria.)

Renzi_1 (06:35) „My rozmawialiśmy językiem prawdy”. (Noi abbiamo parlato nel linguaggio di verità.)

Renzi_1 (07:00) „My wiemy, że przede wszystkim musimy zapytać samych siebie o zdolność do zmiany, jeśli chcemy być wiarygodni”. (Noi sappiamo che prima di tutto dobbiamo chiedere a noi la forza di cambiare se vogliamo essere credibili.)

Renzi_1 (09:53) „Ażeby to mogło się zdarzyć [...] powinniśmy być zdolni do silnego zmagania się z uproszczeniem naszych instytucji i życia europejskiego". (Perché

${ }^{18} \mathrm{~W}$ nawiasie podana jest dokładna lokalizacja zacytowanego fragmentu przemówienia w serwisie internetowym YouTube (minuta i sekunda). 
questo accada [...] dovremmo essere capaci di affrontare con forza la questione della semplicità delle nostre istituzioni e della vita europea.)

Renzi_1 (10:12) „Chcemy budować wszyscy razem”. (Vogliamo costruire tutti insieme.)

Przegląd wypowiedzi polityków pozwala zauważyć wolitywny charakter niektórych wypowiedzi:

Renzi_1 (02:12): „Pozwólcie mi to wyjaśnić żartem”. (Lasciatemelo dire con una battuta.)

Renzi_1 (02:24): „Czy mogę nazwać to z największą troską?” (Posso dirlo con l'estrema preoccupazione?)

Renzi_1 (14:30) „Kończąc, pozwólcie mi to powiedzieć”. (Lasciatemelo dire concludendo.)

Warto podkreślić, że wypowiedzi odwołujące się do woli człowieka skłaniają słuchacza do przyjęcia zaproponowanych treści dyskursu nie na mocy władzy instytucjonalnej. Nie można tu mówić o przewadze nadającego komunikat nad odbiorcą. Prośba nie jest rozkazem, a jednak odbiorca chętniej spełnia prośby niż nakazy. Prośba jako akt mowy obliguje w sferze deontologicznej i moralnej, a nie instytucjonalnej. Mówca posługujący się prośbą apeluje do wrażliwości słuchacza, tym samym objawia szacunek i zaufanie względem mówcy i wystawia mu wysoką ocenę. Adresat przekazu wie, że działa nie z przymusu, ale w wolności. Toteż stanowi swoiste przynaglenie dla słuchacza, by nie zawieść zaufania wysyłającego komunikat ${ }^{19}$. Wolitywny charakter ujawniają niektóre słowa, takie jak proszę, chciatbym, życzę:

Renzi_1 (08:37) „Chcemy to powiedzieć z wielkim spokojem”. (Vogliamo dirlo con grande serenità.)

Renzi_1 (04:23) „Chciałbym być jasny”. (Vorrei essere chiaro.)

Renzi_1 (05:36) „Chciałbym to powiedzieć z wielką jasnością i przekonaniem”. (Voglio dirlo con grande chiarezza e convinzione.)

Renzi_1 (06:04) „Próbuję także powiedzieć”. (Provo anche a dire.)

Grillo_1 (07:16) „Chciałbym wiedzieć, kto powinien ponosić ciężar tego przyjęcia”.

(Voglio sapere chi si deve accollare il peso di questa accoglienza.)

Grillo_1 (10:16) „Chcę, aby ludzie zrozumieli”. (Voglio far capire alla gente.)

Grillo_2 (08:01) „Nie chcę nic wam narzucać, osądźcie wy. Chcę zostawić was w spokoju, jednak chcę przeczytać wam niewielką przypowieść, nazwijmy ją przy-

${ }^{19}$ Por. D. Zdunkiewicz, Językowe środki perswazji w homiliach (na przykładzie tekstów Jana Pawła II), [w:] Język a kultura, t. 4: Funkcje języka i wypowiedzi, red. J. Bartmiński, R. Grzegorczykowa, Wiedza o Kulturze, Wrocław 1991, s. 151. 
powieścią". (Non voglio imporvi nulla, giudicate voi. Voglio lasciarvi in modo sereno, però, voglio leggervi una piccola parabola, chiamiamola parabola.)

Perswazyjność przekazu objawia się w zdaniach gramatycznie rozkaźnikowych, które przybierają formę zdań powinnościowych. Polityk posługujący się tego rodzaju zdaniem stwarza poczucie wspólnoty, bliskości ze słuchaczem, np.: Renzi_1 (05:02) „Naszym wielkim wyzwaniem dziś jest odnaleźć duszę Europy". (La nostra grande sfida oggi è ritrovare l'anima dell'Europa.)

Emfaza, czyli przesadna emocjonalność wypowiedzi, ale także nacisk położony na pewne zdania, wyrazy lub sylaby, uwydatniający ich znaczenie ${ }^{20}$, dostrzegalna jest w następujących wypowiedziach polityków:

Renzi_1 (01:11) „Ze względu na wszystkie te przyczyny jestem szczęśliwy... [oklaski] jestem szczęśliwy i zaszczycony móc reprezentować moją ojczyznę”. (Per tutti questi motivi dunque sono felice...(applauso) sono felice e onorato di rappresentare il mio Paese.)

Grillo_1 (09:35) „Przybyłem tutaj, aby rozmawiać z Wami na serio”. (Sono venuto qua per parlarVi seriamente.)

Grillo_1 (27:25) „Chciałbym dać aplauz tej Pani. Droga Pani, brawo, brawo!” (Vorrei fare un applauso a questa Signora. Cara Signora, bravo, bravo!)

Enumeracja to wyliczanie w tekście kolejnych elementów pewnej całości; ma na celu wzmocnienie wypowiedzi:

Renzi_1 (03:20) „Kiedy myślimy o łączności pomiędzy Grecją i Włochami, nie mamy na myśli rzeczy nadzwyczajnych i zachwycających i bogatych w sugestie, takich jak relacje między Anchizesem i Eneaszem, Peryklesem i Cyceronem, agorą i forum, świątynią i kościołem, Partenonem i Koloseum”. (Se pensiamo al passaggio del testimone tra Grecia e Italia non pensiamo a cose straordinarie e affascinanti e ricche di suggestione, come il rapporto tra Anchise ed Enea, Pericle e Cicerone, l'agora ed il foro, il tempio e la chiesa, il Partenone e il Colosseo.)

Grillo_1 (20:52),_Znajdujemy się tutaj, by zrozumieć, by uprościć, by wyprowadzić na zewnątrz". (Noi siamo qui per capire, per semplificare, per portare fuori.)

Grillo_2 (05:46) „Chcemy pozostać w Europie pięknej, innej, z Francuzami, z Niemcami, chcemy być pośród nich, ponieważ jesteśmy różni, jesteśmy Włochami!” (Vogliamo rimanere in Europa bella, diversa, con i francesi, con i tedeschi, vogliamo starci in mezzo a questa gente qua, perché siamo diversi, siamo italiani!)

${ }^{20}$ Emfaza [hasło], [w:] Stownik języka polskiego PWN, http://sjp.pwn.pl/slowniki/emfaza.html [dostęp: 4.11.2015]. 
Powtórzenie polega na kilkakrotnym użyciu tego samego elementu językowego. Wykorzystywane jest jako jedna z technik perswazyjnych. Stosunkowo często posługiwali się tym środkiem politycy włoscy:

Renzi_1 (03:01) „Chcę dać Wam konkretny przykład, chcę dać go przede wszystkim sobie". (Voglio farvi un esempio concreto, voglio farvi innanzitutto a me.)

Renzi_1 (03:50) „Nie myślimy o tym, kiedy w Europie dyskutujemy o Grecji i Italii, ani nie myślimy o pytaniach dotyczących sensu życia...". (Non pensiamo a questo quando in Europa discutiamo di Grecia e Italia e non pensiamo nemmeno alle domande sul senso della vita...)

Renzi_1 (06:37) „Powiedzieliśmy, że musimy wdrażać nasze reformy, że musimy zmienić biurokrację, sprawiedliwość, system fiskalny, że musimy zmienić instytucje". (Abbiamo detto che noi dobbiamo fare le nostre riforme, che noi dobbiamo cambiare la burocrazia, la giustizia, il sistema fiscale, che noi dobbiamo cambiare le istituzioni.) Renzi_1 (08:37) „Nie chcemy sądzić przeszłości, nie interesuje nas osąd przeszłości, nas interesuje natychmiast rozpocząć przyszłość". (Non chiediamo giudizio sul passato, non ci interessa giudicare il passato, ci interessa iniziare il futuro subito.) Grillo_1 (11:44) „Musimy pomóc zrozumieć, czym jest system. Musimy pomóc zrozumieć, w jakim świecie żyjemy". (Dobbiamo far capire che cos'è questo sistema. Dobbiamo far capire che tipo del mondo viviamo.)

Grillo_1 (20:14) „Zmieniliśmy parlament włoski. Zmieniliśmy politykę włoską”. (Abbiamo cambiato il parlamento italiano. Abbiamo cambiato la politica italiana.)

Grillo_1 (22:40) „Nigdy nie traktowali poważnie polityki fiskalnej. Nigdy nie traktowali poważnie polityki informacyjnej”. (Hanno mai preso sul serio la politica fiscale. Hanno mai preso sul serio la politica dell'informazione.)

Grillo_2 (02:29) „Przyzwyczajamy się do tej zgnilizny, być może przyzwyczajamy się i nawet tego nie dostrzegamy...". (Ci stiamo abituando a questo marcio, forse ci stiamo abituando e non lo percepiamo neanche più...)

Grillo_2 (03:21) „Być może Forza Italia lub Forza Mafia, nazywajcie ją jak chcecie, nie będzie już istnieć [...] może coś się wydarzy, to coś [...] coś się wydarzy!” (Magari Forza Italia o Forza Mafia, chiamatela come volete, non ci sarà più, [...] forse succederà qualcosa, questo qualcosa [...] succederà qualcosa!)

Powtórzenie może również jednocześnie przybrać formę wyznania (confessio): Grillo_1 (09:28) „Zmieniłem moją pracę, zmieniłem moją strukturę myślową". (Ho cambiato il mio lavoro, ho cambiato la mia struttura mentale.)

Szczególnym rodzajem powtórzenia jest anafora, także stosowana w celach perswazji. Polega na powtórzeniu tego samego słowa na początku kolejnych części składowych wypowiedzi ${ }^{21}$ :

${ }^{21}$ Por. E. Kujawska-Lis, Dickenowskie anafory w polskim przekładzie, „Prace Językoznawcze” 
Renzi_1 (07:05) „Italia przychodzi tutaj, by prosić Europę o zmiany, których ona nie jest w stanie dokonać. Italia przychodzi tutaj, by powiedzieć, że ona jako pierwsza chce zmian. Italia przychodzi tutaj, by powiedzieć, że wierzy w instytucje europejskie i przychodzi to powiedzieć z przekonaniem i determinacją". (L'Italia viene qui per chiedere all'Europa i cambiamenti che lei non è in grado di fare. L'Italia viene qui a dire che lei per prima viene a cambiare, viene qui a dire che lei crede nelle istituzioni europee e viene qui per dirlo con la convinzione e con la determinazione.)

Renzi_1 (13:00) „Wy reprezentujecie wielką odpowiedzialność, wy reprezentujecie światło cywilizacji, wy reprezentujecie jako Europa cywilizację globalizacji”. (Voi rappresentate...grande responsabilità, voi rappresentate il faro di civiltà. Voi rappresentate come l'Europa la civilizzazione della globalizzazione.)

Renzi_1 (13:48) „Jeśli nie ma reakcji Europy, jeśli nie ma Waszej reakcji...”. (Se non c'è la reazione dell'Europa, se non c'è la Vostra reazione...)

Anadiploza to ,figura stylistyczna polegająca na rozpoczynaniu nowego zdania, członu zdania lub wersu wyrazem, który znajdował się na końcu zdania lub na końcu wersu poprzedniego" 22 . W analizowanych przemówieniach polityków można odnaleźć jej przykłady:

Renzi_1 (15:56), ,[...] podczas naszego semestru, podczas naszego semestru, kiedy będzie miał miejsce szczyt ASEM w Mediolanie [...]". (...durante il nostro semestre, durante il nostro semestre, quando incontreremo il vertice ASEM a Milano...) Renzi_1 (16:32) „Oto dlaczego, oto dlaczego nie istnieje Italia, która prosi o skróty [...]". (Ecco perché, ecco perché non c'è l'Italia che chiede scorciatoie...)

Grillo_1 (02:00) „Przybyliśmy tutaj, tutaj, tutaj [...] z kampanii prasowej, będącej karygodną informacją, karygodną na jego temat, w której był określany na przykład jako człowiek straszny, homofob, jako rasista, o dziwnych zachowaniach, jako pijak, rzecz nie do pomyślenia". (Siamo arrivati qua, qua, qua ... da una campagna di stampa, dall'informazione vergognosa, vergognosa su di lui per esempio dove veniva dipinto come un uomo terribile, come un omofobo, come un razzista, come che ha i giri strani, come un ubriacone, una roba incredibile.)

Grillo_1 (04:55) „Ten Schulz, Schulz przybył do Włoch, by robić sobie kampanię z pieniędzy europejskich, zatem pieniędzy publicznych, i zrobił kampanię przeciwko mnie, przeciwko mnie, a ja jego nawet nie znam". (Questo Schulz, Schulz che è venuto in Italia a farsi la campagna, lui con i soldi europei, quindi pubblici, e ha fatto la campagna contro di me, contro di me, che non lo conosco neanche.)

2009, z. 11, Uniwersytet Warmińsko-Mazurski, s. 115-117.

${ }_{22}^{2}$ Anadiploza [hasło], [w:] Stownik języka polskiego PWN, http://sjp.pwn.pl/sjp/anadiploza;2549890 [dostęp: 4.11.2015]. 
Grillo_1 (05:10) „Uważaj Schulz, teraz jestem tutaj, jestem tutaj, Schulz. Teraz jest nas tutaj 17-tu, 18-tu ze mną". (Stai attento Schulz, adesso sono qua, sono qua, Schulz. Adesso siamo qua, in 17, più io, in 18.)

Grillo_1 (10:48) „Przestaliśmy myśleć, przestaliśmy myśleć, ludzie boją się myśleć”. (Non pensiamo più, non pensiamo più, la gente ha paura di pensare.)

Grillo_1 (13:59) „Problem w tym, że nie mamy planu B, problem w tym, że nie mamy planu B". (Il problema che non abbiamo piano B, il problema che non abbiamo piano $B$.)

Pytania retoryczne ze swojej natury nie domagają się jakiejkolwiek odpowiedzi, ale raczej sygnalizują problem, podkreślają również perswazyjność przekazu. Figura ta odwołuje się do atencji i współudziału słuchacza. Politycy stosują zarówno interrogatio (ma miejsce wtedy, gdy odpowiedź na pytanie jest dobrze znana), jak i subiectio (pytający sam sobie stawia pytanie i na nie odpowiada) ${ }^{23}$.

Renzi_1 (08:11) „Kto pamięta o tym, że podpisaliśmy pakt stabilizacyjny i pakt rozwoju?" (Chi si ricorda che abbiamo firmato il patto di stabilità e di crescita?)

Renzi_1 (08:52) „Czy mamy jeszcze pragnienie, czy też nie na nowo podjąć grę? Czy mamy jeszcze pragnienie, czy też nie przynależeć do awangardy?" (Abbiamo un desiderio o no di recuperare questo game? Abbiamo un desiderio o no di essere un'avanguardia?)

Grillo_1 (04:34) „Gdzie jest władza? Kim są te osoby nominowane, niewybrane przez nikogo?" (I poteri dove sono? Chi sono queste persone nominate, non elette da nessuno?)

Grillo_1 (06:06) „Jaki rodzaj unii monetarnej sprawiliśmy sobie? Ja tego nie wiem. Co to za rodzaj unii ekonomicznej? [...] Czym jest ta ekonomia europejska?" (Che tipo di unione monetaria ne abbiamo fatto? Io non lo so. Che tipo di unione economica è questa? [...] Che cos'è questa economia europea?)

Grillo_1 (06:30) „Czy potrzebna nam jeszcze Europa? Czy służą jeszcze pieniądze w bankach? Czy potrzebna jest jeszcze dyscyplina?" (Ci serve più Europa? Ci servono più soldi alle banche? Ci serve più rigore?)

Grillo_1 (16:31) „Gdzie jest Unia Europejska? Czym jest Unia Europejska?” (Dove è l'Unione Europea? Cos'è l'Unione Europea?)

Grillo_1 (17:27) „Gdzie idą? Tam, gdzie koszt pracy kosztuje mniej”. (Dove vanno? Dove il lavoro costa meno.)

Grillo_2 (01:01) „Co po 2014 roku, który odchodzi, możemy opłakiwać? Renziego, jego dyskursy? Co może opłakiwać? Zamach na demokrację i na konstytucję dwóch małych partii PD i PDL?" (Cosa potremo rimpiangere del 2014, che se ne va? Renzi,

${ }^{23}$ Por. K. Felsner, H. Helbig, T. Manz, Arbeitsbuch Lyrik, Akademie Verlag GmbH, Berlin 2012, S. 182. 
le balle di Renzi? Cosa potremo rimpiangere? Un attentato alla democrazia e alla costituzione di due partitelli: il PD e il PDL?)

Grillo_2 (06:07) „Dlaczego przestać myśleć o planie B?” (Perché continuare a pensare di non avere un piano $B$ ?)

\section{Sytuacja komunikacyjna wloskich polityków vs. „idealna sytuacja komunikacyjna” Habermasa}

Czy poddane analizie przemówienia polityków spełniają warunki „idealnej sytuacji komunikacyjnej”? Czy i w jaki sposób zastosowane językowe środki perswazji wpływają na spełnienie warunków decydujących o uznaniu bądź nieuznaniu przemówienia polityka za racjonalny fundament legitymizacji demokratycznego systemu politycznego?

Warunek nr 1: równość między partnerami dyskursu.

Formy 1. osoby liczby mnogiej czasownika, zaimek osobowy my i dzierżawczy nasz wskazywałyby na istniejącą równość na linii nadawca przekazu - odbiorca. Podobnie służy temu istnienie zdań gramatycznie rozkaźnikowych, które przybierają formę zdań powinnościowych, a także emfaza. Biorąc pod uwagę czynniki inne niż perswazyjne, należy zauważyć, że w przypadku wystąpienia Berlusconiego na ulicach Rzymu oraz przemówienia Grillo podsumowującego rok 2014, zarejestrowanego w nieoświetlonych pomieszczeniach na wzór starożytnych katakumb, nie można dopatrywać się spełnienia warunku równości między partnerami dyskursu. Tam nie ma partnera dyskursu, to raczej swoisty monolog polityków z obecnymi w dyskursie elementami perswazyjnymi. Z kolei członkowie Parlamentu Europejskiego wraz z przewodniczącym obrad stanowią raczej bierne audytorium dla premiera Renziego oraz lidera partii Ruchu Pięciu Gwiazd Grillo. To wyklucza spełnienie warunku nr 1. Poczucie równości między partnerami dyskursu, której nadają środki perswazji, jest iluzoryczne, wątpliwe.

Warunek nr 2: kompletne ujawnienie procesów deliberacji.

Choć trudno zbadać intencje mówcy, to warunek ten w mojej opinii spełniają wszystkie cztery przemówienia: mówcy konfrontują z sobą i z audytorium własne uczucia, poglądy i emocje. Dowodzą tego dostrzeżone w analizie licznie zastosowane środki językowej perswazji, m.in. pytania retoryczne, emfaza czy wolitywny charakter wypowiedzi.

Warunek nr 3: czasowe wstrzymanie stosunków władzy i dominacji.

Warunek ten nie występuje w poddanych analizie wystąpieniach Berlusconiego i Renziego. Z kolei Grillo w swoich wystąpieniach, poprzez zastosowaną retorykę przekazu, utożsamia się z przeciętnym obywatelem i pragnie być postrzegany raczej jako komik niż polityk. Można przyjąć, że w znaczącej mierze 
w wystąpieniach włoskiego lidera MoVimento 5 Stelle istnieje czasowe wstrzymanie stosunków władzy i dominacji. Wypowiedzi, w których istnieją zdania powinnościowe stwarzają złudne poczucie wspólnoty polityka i audytorium pozbawionej relacji władzy i dominacji.

Warunek 4: wolność wyboru tematu dyskusji.

Warunek ten jest spełniony we wszystkich analizowanych przemówieniach.

\section{Wnioski}

Przeprowadzona analiza kilku zaledwie wybranych przemówień publicznych reprezentantów włoskiej sceny politycznej dowodzi, że użyte słownictwo, składnia, zastosowane figury retoryczne są silnie obecnym w mowie elementem perswazyjnym, używanym z intencją, by przekonać słuchacza do przyjęcia danego punktu widzenia. Politycy dobrze rozumieją mechanizmy teorii komunikacji i potrafią wykorzystywać figury retoryczne w przekazie. Chcą zyskać poparcie słuchacza dla własnych poglądów. Analiza wystąpień Grillo, Renziego i Berlusconiego ujawnia duży stopień emocjonalności przekazu. Dynamiczna, zmieniająca się barwa i siła głosu, towarzysząca temu gestykulacja przekonują o wysokim stopniu emfatyczności dyskursu politycznego. Żadne jednak z analizowanych wystąpień polityków nie spełnia wszystkich kryteriów dyskursu, o których pisał Habermas, by rościć sobie prawo do uznania za racjonalną podstawę legitymizacji demokratycznego systemu politycznego. Odpowiednio zastosowane przez polityków językowe środki perswazji dają subiektywne wrażenie o rzekomo zaistniałej ,idealnej sytuacji komunikacyjnej”, o której pisał filozof. Problemu legitymizacji władzy nie można zawęzić jedynie do zagadnień perswazyjności przekazu, jakkolwiek temat ten stanowi ważny i potrzebny element komunikowania politycznego. Retoryczność przekazu jest ważna, ale bez stosownego etosu mówcy niewystarczająca do tego, by zdobyć akceptację społeczną.

Grillo jest raczej dobrym komikiem, wypowiadającym hasła populistyczne, a nie specjalistą z zakresu ekonomii. Nie przeszkadza mu to jednak wyrażać wielu nowych teorii ekonomicznych, rzekomo rozwiązujących najistotniejsze problemy gospodarcze państwa i Europy. W jego wypowiedziach bardziej niż rzetelna wiedza objawia się dowcip, gestykulacja, wielość figur retorycznych. Z kolei Berlusconi jest politykiem wywołującym bardzo żywe emocje we Włoszech, chociażby ze względu na jego podejrzane kontakty ze światem przestępczym, nieznane źródła olbrzymiego majątku, który zgromadził, czy też skandale obyczajowe. Predyspozycje moralne pozostawiają wiele do życzenia. Renzi stosunkowo krótko sprawuje urząd premiera, nie potrafi jednak zaradzić wysokiemu bezrobociu wśród ludzi młodych oraz napływającej fali nielegalnych emigrantów z Afryki. 
Wydaje się, że poddane analizie przemówienia nie ograniczają sfery wolności odbiorcy, pozwalają na samodzielne myślenie, pomimo dość wysokiego stopnia perswazyjności przekazu. W nawiązaniu do przywołanych wcześniej kryteriów dobrego mówcy według Arystotelesa czy Cycerona Renzi, Berlusconi i Grillo nie zawsze są wierni prawdzie i nie posiadają idealnych kompetencji intelektualnych i moralnych, aby móc prowadzić dyskurs publiczny. Starożytni retorzy stawiają wysokie wymagania także i dzisiejszym reprezentantom świata polityki, dla których przemówienia publiczne są wpisane w powierzoną im misję i w codzienną pracę.

\section{Bibliografia}

Anadiploza [hasło], [w:] Słownik języka polskiego PWN, http://sjp.pwn.pl/sjp/anadiploza;2549890 [dostęp: 4.11.2015].

Arystoteles, Etyka nikomachejska, za: Aristotelis, Ethica Nicomachea, recognovit F. Susemihl, Teubner, Lipsiae 1880.

Arystoteles, Etyka wielka, [w:] tenże, Dzieła wszystkie, t. 5, przeł. D. Gromska, Wydawnictwo Naukowe PWN, Warszawa 1996, s. 338-344.

Baciak P., Internet - Agora XXI wieku? Rozważanie w świetle teorii demokracji deliberatywnej autorstwa Jürgena Habermasa, „Global Media Journal - Polish Edition” 2006, nr 2 (2), s. 136-139, http://globalmediajournal.collegium.edu.pl/artykuly/jesien\%202006/Baciak-Internet\%20-\%20Agora\%20XXI\%20wieku.pdf [dostęp: 4.11.2015].

Beppe Grillo: humorysta, bloger, polityk, http://pl.euronews.com/2012/05/22/beppe-grillo-humorysta-bloger-polityk/ [dostęp: 4.11.2015].

Capek-Habekovič R., Palaich S., Parola a te!, Heinle Cengage Learning, Boston 2009, p. 47.

Chi c'è dietro Beppe Grillo? Ritratto di Casaleggio, lo stratega 5Stelle, http://www.iltempo.it/politica/2012/10/01/chi-c-e-dietro-beppe-grillo-ritratto-di-casaleggio-lo-stratega-5stelle-1.3130 [dostęp: 11.02.2015].

Cyceron M.T., O mówcy, przeł. B. Awianowicz, Wydawnictwo Antyk, Warszawa 2011.

Daconto C., I 10 politici più importanti del 2014, http://www.panorama.it/news/politica/i-10-politici-piu-importanti-2014/ [dostęp: 4.11.2015].

Dziurlikowska I., Włoska prezydencja pod znakiem rozwoju, http://www.uniaeuropejska.org/wloska-prezydencja-pod-znakiem-rozwoju [dostęp: 4.11.2015].

Emfaza [hasło], [w:] Słownik języka polskiego PWN, http://sjp.pwn.pl/slowniki/emfaza.html [dostęp: 4.11.2015].

Felsner K., Helbig H., Manz T., Arbeitsbuch Lyrik, Akademie Verlag GmbH, Berlin 2012.

Fras J., Komunikacja polityczna. Wybrane zagadnienia gatunków i języka wypowiedzi, Wydawnictwo UWr, Wrocław 2005.

Gimmler A., Deliberative Democracy, the Public Sphere and the Internet, „Philosophy \& Social Criticism" 2001, Vol. 27, pp. 21-39.

Habermas J., Vorstudien und Ergänzungen zur Theorie des kommunikativen Handelns, Frankfurt am Main 1984.

Http://www.repubblica.it/2004/a/sezioni/politica/festaforza/discesa/discesa.html [dostęp: 4.11.2015]. 
Kujawska-Lis E., Dickenowskie anafory w polskim przekładzie, „Prace Językoznawcze” 2009, z. 11, Uniwersytet Warmińsko-Mazurski, s. 115-133.

Kwintylian, Kształcenie mówcy. Księgi I, II i X, przeł. i oprac. M. Brożek, Ossolineum, Wrocław 1951.

Matteo Renzi, la mia storia. Chi sono, http://www.matteorenzi.it/chi-sono/ [dostęp: 4.11.2015].

Nieć M., Komunikowanie społeczne i media. Perspektywa politologiczna, LEX Grupa Wolters Kluwer, Warszawa 2010.

Pisarek W., Perswazja - jak ją widza, jak ją pisza, [w:] Język perswazji publicznej, red. K. Mosiołek-Kłosińska, T. Zgółka, Wydawnictwo Poznańskie, Poznań 2003, s. 9-17.

Przemówienie B. Grillo podsumowujące rok 2014, 31.12.2014, http://www.beppegrillo.it/videos/0_s49orvgm.php [dostęp: 4.11.2015].

Przemówienie B. Grillo w Parlamencie Europejskim w Strasburgu, 2.07.2014, https://www.youtube.com/watch?v=cbkaEeG721Y [dostęp: 4.11.2015].

Przemówienie premiera M. Renzi w Parlamencie Europejskim w Strasburgu, 2.07.2014, http:// archivio.internazionale.it/news/unione-europea/2014/07/02/il-discorso-integrale-di-matteorenzi-al-parlamento-europeo [dostęp: 4.11.2015].

Przemówienie S. Berlusconiego jako senatora, 28.11.2013, https://www.youtube.com/watch?v=go4FPwf0aVI [dostęp: 4.11.2015].

Silvio Berlusconi, http://ludzie.wprost.pl/sylwetka/Silvio-Berlusconi/ [dostęp: 4.11.2015].

The world's 50 most powerful blogs, http://www.theguardian.com/technology/2008/mar/09/blogs [dostęp: 4.11.2015].

Żardecka-Nowak M., Demokracja deliberatywna jako remedium na ponowoczesny kryzys legitymizacji władzy, „Teka Komisji Politologii i Stosunków Międzynarodowych. Polska Akademia Nauk Oddział w Lublinie" 2008, III, s. 29-40, http:/www.pan-ol.lublin.pl/wydawnictwa/TPol3/Zardecka.pdf [dostęp: 4.11.2015].

Zdunkiewicz D., Językowe środki perswazji w homiliach (na przykładzie tekstów Jana Pawła II), [w:] Język a kultura, t. 4: Funkcje języka i wypowiedzi, red. J. Bartmiński, R. Grzegorczykowa, Wiedza o Kulturze, Wrocław 1991, s. 149-157.

\section{Rafał Leśniczak}

\section{The Persuasiveness of Message and the Problem of Legitimacy}

\section{(Summary)}

The author analyses several selected speeches of Italian politicians: the founder of the Forza Italia party, Silvio Berlusconi; founder and leader of the Movement Five Stars, Beppe Grillo; and the current Prime Minister of Italy, Matteo Renzi. The study makes it possible to evaluate whether the conditions for the ideale Sprechsituation of Jürgen Habermas is fulfilled in analysing public discourse. Particular attention will be given to the relationship between the persuasiveness of communication and the problem of legitimacy.

Key words: persuasiveness, political communication, the ideal situation of speech, emphasis, the legitimacy of power. 